Journal of Southeast Asian

2014

\title{
Book Review: Vietnamerica: A Family's Journey, by GB Tran
}

Candie Sanderson

University of Montana, candie.s.sanderson@gmail.com

\section{Recommended Citation}

Sanderson, Candie (2014) "Book Review: Vietnamerica: A Family's Journey, by GB Tran," Journal of Southeast Asian American Education and Advancement. Vol. 9 : Iss. 1, Article 3.

DOI: $10.7771 / 2153-8999.1078$

Available at: https://docs.lib.purdue.edu/jsaaea/vol9/iss1/3

This document has been made available through Purdue e-Pubs, a service of the Purdue University Libraries. Please contact epubs@purdue.edu for additional information.

This is an Open Access journal. This means that it uses a funding model that does not charge readers or their institutions for access. Readers may freely read, download, copy, distribute, print, search, or link to the full texts of articles. This journal is covered under the CC BY-NC-ND license. 
WWW.JSAAEA.org

\title{
Tran, GB. (2011). Vietnamerica: A Family's Journey. New York, NY: Villard. 288 pp. \$30.00 (Hardcover). ISBN: 978-0345508720
}

\author{
Reviewed by \\ Candie Sanderson \\ University of Montana
}

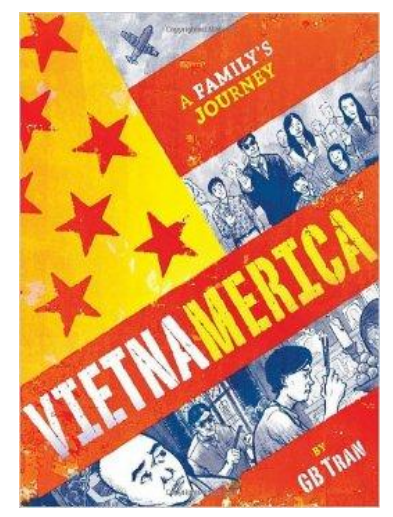

Vietnamerica: A Family's Journey, by GB (Gia-Bao) Tran, published by Villard in 2011, is the first Vietnamese American graphic-memoir. Following in the footsteps of Art Spiegelman's Maus (1991) and Marjane Satrapi's Persepolis (2000), GB Tran chose the graphic form to illustrate a conflict-ridden period of history and explore his own family narrative from his grandparents' lives in Vietnam during the French occupation, to his parent's struggles during the Vietnam war and their escape from Vietnam a few days before the fall of Saigon in 1975, to their life as immigrants and refugees in the United States with GB and his halfsiblings. Vietnamerica is the story of a second-generation Vietnamese American's quest for his origins and progressive discovery of his family's complex history and long-kept secrets. Born in 1976 in North Carolina, Tran grew up immersed in American culture and uninterested in his parents' past and invitations to travel to Vietnamthat is, until his first trip in 2001, which prompted him to come back, five years later, to interview family members and friends. Vietnamerica mirrors this journey: from a disinterested son, clueless as to his parent's past struggles, the character of GB evolves throughout the book towards that of a young man determined to understand and preserve his family's history. Yet, Vietnamerica isn't a traditional coming-of-age story; instead of focusing on himself, as one might expect in a memoir, Tran retreats into the background to give voice to his family and let their memories unfold, across pages full of strikingly detailed graphics, and intricate storytelling.

Vietnamerica doesn't follow a linear, chronological progression. Instead, the narrative goes back and forth between multiple generations, alternating flashbacks and present time, interweaving GB's questions and his parents' answers. Before the narrative even starts, Tran gives us a useful overview of "The Cast," which puts a name and a face-sometimes multiple, so as to show the passing of time - on each major character of the story. This family tree proves a useful tool when trying to navigate the narrative's multiple layers. Tran's graphic-memoir is divided into a dozen sections, each separated by a colored page and/or a double-page symbolic illustration: in one of them, the author draws an auto-portrait where the faces of his parents, in the background, join to create some of his own features. Many of Vietnamerica's sections start with a small illustration of GB's mother, Dzung Chun Tran, telling him about the family's past, while cooking. These breaks help situate the narrative in time, and create some breathing room

\section{(c)}

SOMERIGHISRESEREED Readers are free to copy, display, and distribute this article, as long as the work is attributed to the author(s) and the Journal of Southeast Asian American Education \& Advancement, it is distributed for noncommercial purposes only, and no alteration or transformation is made in the work. More details of this Creative Commons license are available at http://creativecommons.org/licenses/by-nc-nd/3.0/. All other uses must be approved by the author(s) or JSAAEA. 
for the reader. "Your father and I married in 1973 ..." (p. 118) the mother explains, then, "By 1974, the war between the North and the South was getting much worse ... " (p. 160).

The book opens in 2006, when GB and his family travel back to Vietnam for Thi-Mot's funeral, GB's maternal grandmother, which takes place only a few months after Huu Nghiep's death, GB's estranged paternal grandfather. In the first few pages, in spite of the fact that this is his second trip, GB seems disoriented: ignorant of Vietnamese mourning customs, he wears black instead of white, expects solemnity and sadness instead of a boisterous family reunion, is shocked to see that Do, a family's friend, is not embittered by his experience in labor camp, but keeps an optimistic outlook on life. GB asks many naïve questions, which lead his father to say, "You can't look at your family in a vacuum and apply your myopic contemporary Western filter to them" (p. 13). The book certainly avoids this pitfall.

The following section immediately jumps back many years, to the aftermath of World War II and the beginning of the conflict between French colonizers and the Vietminh. GB's parents' childhoods-his mother's in the North, his father's in the South-were shaped by political conflict: both had to leave their hometowns to hide in caves or jungles, and live in different cities such as Saigon or Langson. GB's paternal grandmother, beautiful and educated Le Nhi, is abandoned by her husband who left to join the revolutionaries, and places herself under the protection of a French colonel, with whom she develops a romantic relationship and has a son. Meanwhile, Thi-Mot remarries after her husband is accidently shot by a French soldier. She too bears children from her new husband. "In wartime, families did what they needed to survive" (p. 45), GB's mother explains.

The next section brings the reader back to the present and shows the Trans getting ready to go back to Vietnam. What they find upon their arrival is overwhelming: Tran's illustrations show busy, crowded streets where the Vietnamese star stands alongside the McDonald's logo. GB's parents struggle to find traces of their childhoods in the new landscape, or are reluctant to remember traumatic memories. GB's father, Tri Huu Tran cannot stay in their hotel room because the small, narrow window, reminds him of his days in prison, back when he was arrested for being the son of Vietminh hero, Huu Nghiep. The pages about Tri's imprisonment allow Tran to retrace his father's early years as an aspiring artist, in love then married to a French woman, who gave him a daughter, Lisa, and a son, Manny, before leaving him. The following section depicts the Trans children's lives in the United States, Lisa and Manny's strict education-which GB knew seldom about, being the youngest and a half-brother-the parents' reluctance to reveal secrets from their past, the family's struggles to adapt to a new culture- "Vietnamese rules and responsibilities on one side and allure of American freedoms of the other," as Manny describes it (p. 110) — and Le-Nhi's sickness and death.

The next three segments focus on GB's parents relationship, going back and forth between their argument-ridden life in the United States, and their years of struggle in Vietnam. Tran retraces his parents' courtship, back when Tri was a teacher and Dzung his student, their friendship with an American, Dzung's half-brother Vinh's years in the army. He then explains the circumstances of their marriage, which Le-Nhi disapproved of, but Thi-Mot agreed to, thanks to Tri's friend Do's scheme. "By 1974, the war between the North and the South was getting much worse," (p. 160) GB's mother explains, as the narrative recounts history and explains Tri's forced decision to leave Vietnam-without Dzung knowing. The next section uses GB's parents' trip back to Vietnam in 1994 - and GB's refusal to go - as an occasion to explore Huu Nghiep's past, Tri's father and GB's grandfather. Huu Nghiep left his family to join the Vietminh to gain independence from the French, quickly "climbed the Vietminh's chain of command" (p. 190) and 
remained in the revolutionary forces throughout the Vietnam War. As Tri reunites with his father during his 1994 trip, the old man recounts his search for his son after the conflict, when Tri had already left for the United States, and gives him artifacts from his days as a revolutionary. The theme of heritage is further developed, as the section ends on another important father-son moment: Tri gives GB a book on the Vietnam War as a graduation present. Tran explains about his parents' trip: "It was then that they realized their Vietnam only existed in stories and fading memories" (p. 207) and adds, they hoped "that someday I'd want to learn" (p. 207).

The two next segments retrace the year 1975: Tri's success as a painter, the family's happiness and stability, interrupted by the escalation in the Vietnamese-American conflict, Tri's decision to leave Vietnam, lying to Dzung who would have never agreed to leave her family behind, and, finally, the end of the Vietnam war. The second to last section shows the Trans' arrival to the United States, and flashes forward to GB as a young man, asking questions about the family's past to many of his family members: his eagerness to understand the past and his cluelessness as to what lens to read it through are very apparent. Following a beautiful illustration featuring a plane in flight, with pictures of the Trans' life in Vietnam on the left, and in the United States on right, the book ends on Tri and Dzung's escape from Saigon with Le-Nhi and their three children, in the midst of the chaos, as their American friend manages to find them seats on one of the last planes to leave Saigon before the fall. Nine black pages, six of them featuring the slow fall of a leaf, bring us slowly back to 2001, where GB, who has just moved on his own to New-York City from Arizona, unpacks to find the Vietnam War book his father gave him, and calls his mother to ask, "Can I still go to Vietnam with you?" (p. 279).

Readers might find Tran's non-linear narrative confusing, but his constant back-and-forth and the density of his narrative, coupled with his attention for details in his illustrations, mirrors the way in which memory functions, especially when trauma is involved. The Vietnamese immigrant experience is not one smooth picture, but a multitude of puzzle pieces - as the hardcover under the dust jacket shows - which may fit only in places. Tran uses the image of the tree as one of his central metaphors. "A man without history if a tree without roots - Confucius" (p. 8) GB's father writes to his son, on a note which opens and closes the graphic-memoir. As GB digs to find his roots, he finds a multiplicity of interconnected threads, reaching deep into the earth and growing high into the sky, in a flurry of entangled branches. The ramifications of the narrative are reminiscent of that complex, organic structure which weaves in together Vietnam's history, a family's journey, and the author's own attempt to reach for his origins. Tran's tone is rather neutral and he chooses to let his images and words speak for themselves, instead of overwhelming the reader with commentary or historical information. The reader looking for strong narrative guidance might be disappointed, as the narrative is presented to her just as it was to GB, in bits and pieces, and never in order, with repetitions, questions, and perhaps even contradictions.

However, Tran's talent as a graphic artist allows the story to come to life in vivid colors and great details. Even if the reader might need to go back to the original "cast" in order to identify each character correctly, Tran also gives his characters distinctive features so as to help the reader recognize them: Le Nhi wears square classes, Thi Mot round ones, Uncle Vinh a hat, Tri sunglasses etc. Furthermore, the font in which the characters speak changes. Tri always speaks in capital letters, which suggest his authority and imposing fatherly presence. Dzung's words, on the other hand, are rendered in delicate cursive. The illustrations are dense, sometimes crowded, but also spare when they need to be, like when the Tran grandchildren line up in the hospital's hallway to pay their last respects to their dying grandmother, Le Nhi. Tran's use of 
color is particularly interesting. The hospital scene, for example, is rendered in cold grays and blues. Elsewhere, the deep red of the Vietnamese flag and of the Vietnam War book contrast starkly with Tran's subdued pastel palette. Tran's colors also help identify the different narrative threads: Dzung's story is almost always told in hues of blue, while Tri's is often brown. The parents' courtship years are depicted in sophisticated black and white drawings, while Tri's younger years are more colorful and cartoonish-simplistic compared to the intricate illustrations of present day Vietnam. The parents' marriage's early happy years are full of light and feature mostly coastal landscapes.

Tran's artistic talent is evident in his depiction of Vietnam's diversity, from the crowded streets of Saigon to the small village of Langson, from the lush jungle to the desolate mountains. In modern day Vietnam, a Hilton sign, a McDonald's fry cone, and an Italian restaurant stand alongside street vendors with traditional Vietnamese hats. The full and sometimes double page illustrations provide for striking symbols either of Vietnam's history of Tran's family's journey. One of them shows Vietnam as a fault line squeezed in between the South China Sea and Cambodia. The Vietnamese are trapped in the crack, while grabbing for elusive ships on one side, and holding on to Cambodia's cliffs on the other. Simplistic, communist propaganda-like drawings in blue, yellow, and red depict identical soldiers in a file, while Vietnam's hand lifts up a family towards a red dove, symbol of peace. A two-page picture of a game of scrabble sums up the Trans' life as immigrants. Areas of the board display images of the family's life: Le Nhi sleeps in a bed while the parents and three children sleep on cots on the floor, Manny is bullied at school, Dzung pays at the supermarket in food stamps, Lisa is dressed in a Madonna-type outfit, while Manny is staring at a video game, under the eye of his disapproving father - the world "foreign" is misspelled "foriegn" (pp. 108-109).

As many other Vietnamese American memoirs, Tran's Vietnamerica pictures individuals caught in the whirlwind of history, in a conflict bigger than them and which forced them to make difficult choices. "Individuals, not families, pick sides" (p. 33), Dzung reminds GB, emphasizing the value of family ties. However, in spite of the fact that it focuses on one family only, Tran's memoir encompasses about half a century of Vietnamese history: from the French occupation, to the rise of communism, to the Vietnam War, and, later, the chaotic move towards modernization. Tran's narrative is somewhat apolitical. French, Americans, and Vietnamese communists are all represented, but not in a Manichean fashion. Individuals seem to matter more than groups: Tri's American friend helps his family escape, while another American soldier tries to prevent them from getting on the plane, a French soldier kills Thi-Mot's husband, but a French colonel helps take care of Le Nhi's children. It is however difficult to find a positive communist figure in the book: Huu Nghiep, the Vietminh hero, abandoned his family and Tri appears determined not to forgive him.

Vietnamerica, however, does not pretend to be an unbiased historical document, but is, rather, the product of one individual's desire to understand his origins and his parents' immigration story. This graphic-memoir is likely to attract a large audience: from graphic novel aficionados, to scholars of Vietnamese American immigrant literature, to general readers curious to learn more about Vietnam's twentieth-century history and the Vietnamese American experience. The fact that Tran chose the graphic form to tell his family's story adds an interesting twist to the traditional immigrant memoir genre. The striking visuals and popular form are likely to make the book more accessible to those who may be rebuked by the terms "art" or "literature." One can hope that Vietnamerica will do for the Vietnamese American immigrant experience what Satrapi's Persepolis (2000) did for Iran's history during and after the Islamic Revolution: 
that is, bring to the general public an approachable, poignant, and entertaining narrative, help raise awareness of world history, and encourage the new generation to explore its multi-cultural past. Vietnamerica is not just a book about the Vietnam war, neither is it just a coming-of-age story, but an urgent attempt to give voice to a narrative from the past, before it is too late and all the voices are silent, their secrets forgotten with them. "'Our parents care for us as our teeth sharpen ... So we care for them as theirs dull'" (p. 24), Tran writes, quoting an old Vietnamese saying. By putting his parents' story on to the page, he used his artistic talent to do just that.

\section{References}

Satrapi, M. (2000). Persepolis. Paris: L'Association.

Spiegelman, A. (1991). Maus. New York, NY: Pantheon Books.

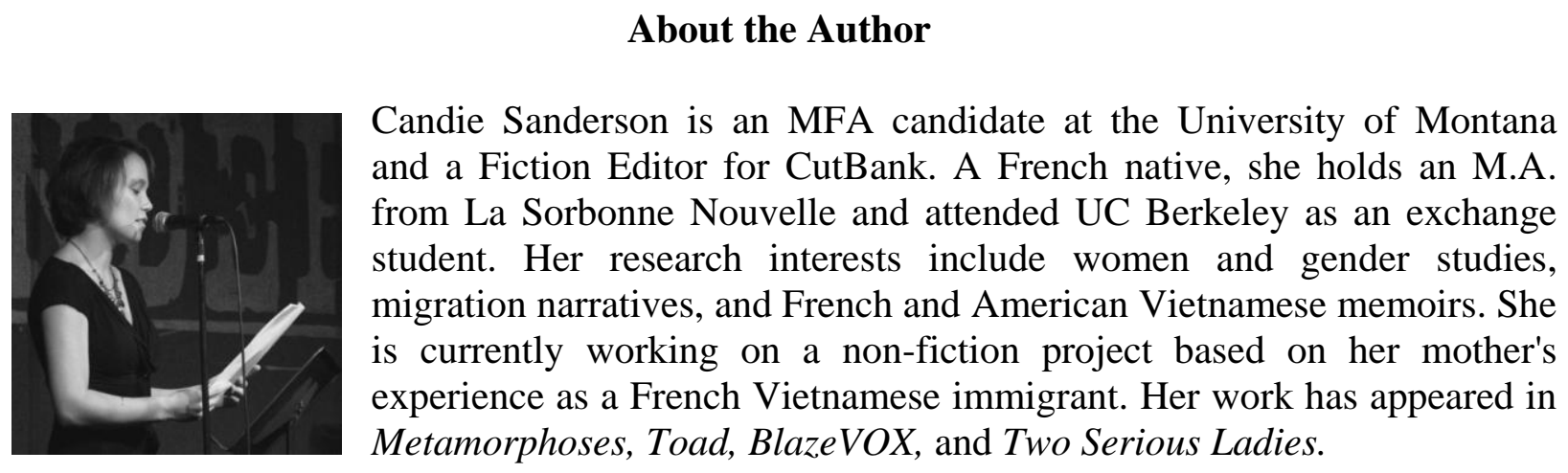


JSA AEA

Journal of Southeast Asian American Education \& Advancement

Volume 9 (2014)

WWW.JSAAEA.org

\section{Editor}

Dr. Wayne E. Wright

University of Texas at San Antonio

\author{
Associate Editors \\ Dr. Chhany Sak-Humphry \\ University of Hawaii at Manoa
}

Dr. Phitsamay Sychitkokhong Uy

University of Massachusetts, Lowell

\section{Book Review Editor}

Dr. Vichet Chhuon

University of Minnesota

\section{Creative Works Editor}

Bryan Thao Worra

Lao Assistance Center

\section{Special Advisor}

Gregory Green

Curator, Echols Collection on Southeast Asia, Cornell University Library

\section{Journal Manager}

Yeng Yang

University of Texas at San Antonio

\section{Editorial Assistant}

Matthew Kraft

University of Texas at San Antonio
A peer-reviewed

scholarly journal published by the National Association for the Education \& Advancement of Cambodian, Laotian, and Vietnamese Americans (NAFEA)

Comments and questions for the editorial staff may be directed to jsaaea@ lists.sis.utsa.edu

\section{Editorial Review Board}

Dr. Steve Arounsack

California State University, Stanislaus

Dr. Phala Chea

Lowell Public Schools

Dr. Loan Dao

University of Massachusetts, Boston

Dr. Changming Duan

University of Missouri, Kansas City
Dr. Carl L. Bankston III

Tulane University

Dr. George Chigas

University of Massachusetts, Lowell

Dr. Hien Duc Do

San Jose State University

Dr. Sophal Ear

U.S. Naval Postgraduate School

Journal of Southeast Asian American Education \& Advancement, Vol. 9 (2014) 


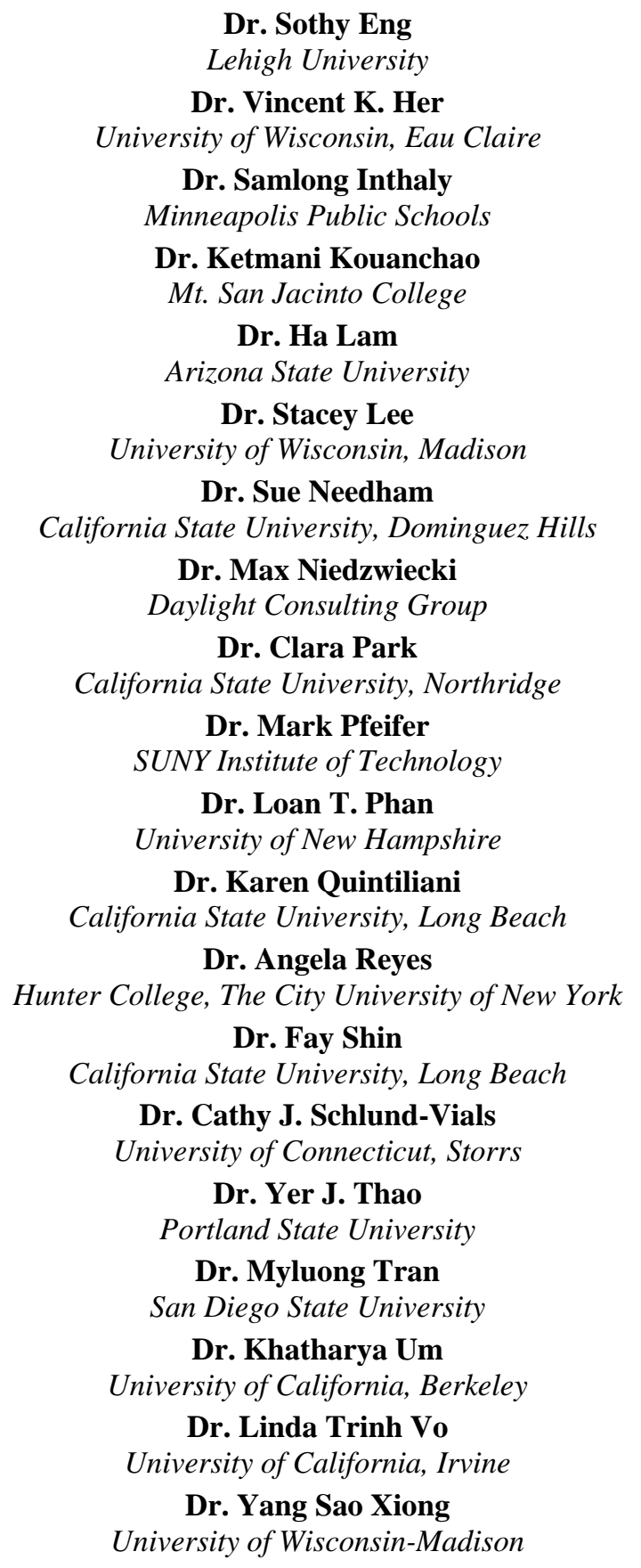

Dr. Vincent K. Her

University of Wisconsin, Eau Claire

Dr. Samlong Inthaly

Minneapolis Public Schools

Dr. Ketmani Kouanchao

Mt. San Jacinto College

Dr. Ha Lam

Arizona State University

Dr. Stacey Lee

University of Wisconsin, Madison

Dr. Sue Needham

California State University, Dominguez Hills

Dr. Max Niedzwiecki

Daylight Consulting Group

Dr. Clara Park

California State University, Northridge

Dr. Mark Pfeifer

SUNY Institute of Technology

Dr. Loan T. Phan

University of New Hampshire

Dr. Karen Quintiliani

California State University, Long Beach

Dr. Angela Reyes

Hunter College, The City University of New York

Dr. Fay Shin

California State University, Long Beach

Dr. Cathy J. Schlund-Vials

University of Connecticut, Storrs

Dr. Yer J. Thao

Portland State University

Dr. Myluong Tran

San Diego State University

Dr. Khatharya Um

University of California, Berkeley

Dr. Linda Trinh Vo

University of California, Irvine

Dr. Yang Sao Xiong

University of Wisconsin-Madison

Dr. Kou Yang

California State University, Stanislaus
Dr. Jeremy Hein

University of Wisconsin, Eau Claire

Dr. Nancy H. Hornberger

University of Pennsylvania

Dr. Peter Nien-Chu Kiang

University of Massachusetts, Boston

Dr. Kevin K. Kumashiro

University of Illinois, Chicago

Dr. Jonathan H. X. Lee

San Francisco State University

Dr. Monirith Ly

Texas State University-San Marcos

Dr. Bic Ngo

University of Minnesota

Dr. Leakhena Nou

California State University, Long Beach

Dr. Isabelle Thuy Pelaud

San Francisco State University

Dr. Giang Pham

University of Massachusetts

Dr. Bounlieng Phommasouvanh

Minnesota Department of Education

Dr. Kalyani Rai

University of Wisconsin, Milwaukee

Dr. Soveacha Ros

Royal University of Phnom Penh

Dr. Nancy J. Smith-Hefner

Boston University

Dr. Christine Su

Ohio University

Dr. Loan Tran

University of California, Riverside

Dr. Tinou Tran

Alief Independent School District

Dr. Silvy Un

Frost Lake Elementary School

Dr. Terrence G. Wiley

Center for Applied Linguistics

Dr. Zha Blong Xiong

University of Minnesota

\section{Doctoral Student Editorial Review Board}

Sovicheth Boun

University of Texas at San Antonio

Keo Chea-Young

University of Pennsylvania

Dung Mao

University of Minnesota
Virak Chan

University of Texas at San Antonio

Annie BichLoan Duong

San Joaquin County Office of Education

Peter Tan Keo

Columbia University

Journal of Southeast Asian American Education \& Advancement, Vol. 9 (2014) 
Journal of Southeast Asian American Education and Advancement, Vol. 9 [2014], Iss. 1, Art. 3

Sanderson-Book Review of Vietnamerica: A Family's Journey

Ravy Lao

University of California, Santa Barbara

Thien-Huong Ninh

University of Southern California

Malaphone Phommasa

University of California, Santa Barbara

Alisia Tran

University of Minnesota
Minh Mai

University of Wisconsin-Madison

Hoa Nha Nguyen

Boston College

Vanna Som

Harvard University

Krissyvan Truong

Claremont Graduate University

\section{Lesley Yang}

University of Minnesota

Journal of Southeast Asian American Education \& Advancement, Vol. 9 (2014)

https://docs.lib.purdue.edu/jsaaea/vol9/iss1/3 